\title{
Alternatives for nitrate and nitrite in fermented meat products: potential contribution of the nitric oxide synthase activity of coagulase-negative staphylococci
}

María Sánchez Mainar*, Stefan Weckx, Luc De Vuyst, Frédéric Leroy

From Genes and nutrition, is personalised nutrition the next realistic step?

Brussels, Belgium. 25 April 2014

\section{Background}

Nitrosomyoglobin, which is the cured colour of fermented meat products, results from the interaction between muscle-based myoglobin and nitric oxide (NO) [1]. NO originates from the addition of nitrate and/or nitrite as curing agents to the meat batter. During fermentation, nitrate is reduced into NO-yielding nitrite by coagulasenegative staphylococci (CNS), present in the meat or added as starter culture [2]. However, health concerns related to the consumption of cured meats are leading to research for alternatives to generate the cured colour. A yet poorly explored pathway could potentially be based on the action of nitric oxide synthase (NOS), which produces NO from arginine. Bacterial NOS activity has only been scantily described, particularly its potential presence in meat-related bacteria and its dependency on environmental conditions. Based on preliminary attempts [3], and because up to now none of the sequenced Lactobacillus species contain a NOS homologue [4], this study focused on meat-related CNS.

\section{Materials and methods}

A genotypic screening for the presence of the NOSencoding gene and a phenotypic screening for the conversion of arginine via NOS activity and other alternative pathways metabolising arginine were performed for 88 CNS strains. Also a complementary screening for potential NOS-stimulating conditions and a kinetic analysis of

\footnotetext{
* Correspondence: Maria.Sanchez@vub.ac.be

Research Group of Industrial Microbiology and Food Biotechnology, Faculty of Sciences and Bioengineering Sciences, Vrije Universiteit Brussel, B-1050
} Brussels, Belgium

possible NOS activities in CNS were done in laboratory fermentors and meat models.

\section{Results}

The genetic potential for NOS activity was frequently found among CNS strains. The phenotypic screening confirmed that arginine metabolism was common, which resulted in mixtures of citrulline and mostly ornithine, with considerable variability on species and strain level, indicative of arginine deiminase activity. The production of citrulline without ornithine formation, indicative of potential NOS activity, was not found under the conditions tested, except for the strain S. haemolyticus G110. However, kinetic experiments indicated that $S$. haemolyticus $\mathrm{G} 110$ was not able to demonstrate NO-driven colour formation in fermented meats, highlighting the importance of technological adaptation of functional candidate strains. Attempts to express the nos gene in other CNS strains were unsuccessful, suggesting that the genetic potential is not commonly expressed by CNS.

\section{Conclusions}

The use of NOS-positive bacterial cultures for nitrate and nitrite cutback in fermented meats is not straightforward. A bottleneck seems to be on the gene expression level, whereas phenotypically positive strains also need to be technologically adapted to the meat fermentation process.

Published: 6 June 2014 


\section{References}

1. Ordónez J, Hierro E, Bruna J, De la Hoz L: Changes in the components of dry fermented sausages during ripening. Crit Rev Food Sci Nutr 1999, 39:329-367.

2. Leroy F, Verluyten J, De Vuyst L: Functional meat starter cultures for improved sausage fermentation. Int J Food Microbiol 2006, 106:270-285.

3. Morita H, Sakata R, Nagata Y: Nitric oxide complex of iron (II) myoglobin converted from metmyoglobin by Staphylococcus xylosus. J Food Sci 1998, 63:352-355.

4. Crane B, Sudhamsu J, Patel B: Bacterial nitric oxide synthases. Annu Rev Biochem 2010, 79:445-470.

doi:10.1186/2049-3258-72-S1-04

Cite this article as: Sánchez Mainar et al:: Alternatives for nitrate and nitrite in fermented meat products: potential contribution of the nitric oxide synthase activity of coagulase-negative staphylococci. Archives of Public Health 2014 72(Suppl 1):O4.

\section{Submit your next manuscript to BioMed Central} and take full advantage of:

- Convenient online submission

- Thorough peer review

- No space constraints or color figure charges

- Immediate publication on acceptance

- Inclusion in PubMed, CAS, Scopus and Google Scholar

- Research which is freely available for redistribution

Submit your manuscript at www.biomedcentral.com/submit 